\title{
A Legal and Economic Analysis of the Cost- Plus Contract Exception in Hanover Shoe and Illinois Brick
}

Section 4 of the Clayton Act creates a treble-damage action in favor of "any person who shall be injured in his business or property by reason of anything forbidden in the antitrust laws." $\mathrm{Su}$ preme Court cases have qualified the statutory language, however. In Hanover Shoe, Inc. v. United Shoe Machinery Corp., ${ }^{2}$ the Court rejected an argument by antitrust defendants that the direct-purchaser plaintiff had sustained no injury because it had passed any overcharge on to its own customers. In Illinois Brick Co. v. Illinois, ${ }^{3}$ the Court dealt with the obverse situation: it refused to countenance a section 4 suit in which a customer plaintiff urged that the burden of an overcharge had ultimately come to rest on it. The rule thus formulated, which generally bars the use of defensive and offensive pass-on theory, ${ }^{4}$ is one of the more controversial areas of antitrust law. ${ }^{B}$ An aspect of that controversy

315 U.S.C. § 15 (1976). The statute also allows "the cost of suit, including a reasonable attorney's fee" to successful plaintiffs.

2 392 U.S. 481 (1968). The plaintiff, a shoe manufacturer, sued to recover overcharges on the cost of shoe manufacturing machinery supplied by the defendant.

431 U.S. 720 (1977). The buyers of buildings sued to recover an overcharge on the price of the defendants' concrete blocks. The overcharge allegedly was passed on from the manufacturers through general and masonry contractors to the plaintiffs.

- See text and notes at notes 11-29 infra.

- For a sampling of the academic controversy, compare Landes \& Posner, Should Indirect Purchasers Have Standing to Sue Under the Antitrust Laws? An Economic Analysis of the Rule of Illinois Brick, 46 U. CHI. L. REv. 602 (1979) with Harris \& Sullivan, Passing On the Monopoly Overcharge: A Comprehensive Policy Analysis, 128 U. PA. L. Rev. 269 (1979). Congress has been no less divided. Repeated legislative attempts to repeal the Court's rule have thus far been unsuccessful. For a discussion of the leading current proposal, S. 300, see Note, Congressional Authorization of Indirect Purchaser Treble Damage Claims: The Illinois Brick Wall Crumbles, 47 FordhaM L. Rev. 1025 (1979). At present, the legislation has passed the Senate Judiciary Committee but is being kept off the floor by the threat of a filibuster. The House has yet to act on a companion measure. 946 ANTITRUST \& TRADE REg. REP. (BNA) A-11 (1980). For conflicting estimates of the bill's prospects for passage from the majority and minority counsel for the Senate Committee, see Regnery, 
that has as yet been little noticed is the growing disagreement about the meaning of the judicially created cost-plus contract exception to the general rule. ${ }^{8}$ Some recent decisions ${ }^{7}$ state that passon theory is now available only where the transactions in question have been carried out under a preexisting cost-plus contract ${ }^{8}$ to supply a fixed quantity of goods. Other opinions ${ }^{9}$ suggest that the "functional equivalent" of such a contract suffices to bring a transaction within the exception.

This comment contends that, despite the superficial appeal of the functional equivalent argument, nothing less than a preexisting, cost-plus, fixed-quantity contract should suffice to invoke the exception. The policies enunciated by the Supreme Court in creating the rule and the exception, and the economic explanation that supports those policies, lead to the conclusion that the exception should not be interpreted expansively. ${ }^{10}$

\section{BACKGROUND}

Before considering the present dispute about the extent of the cost-plus contract exception to the no-pass-on rule, it is necessary to understand what pass-on is, why the Court rejected its use in antitrust cases, and how and why the Court created the exception.

\section{A. Definition of Pass-On}

In order to recover treble damages under section 4 of the Clayton Act, a plaintiff must demonstrate both that a violation of the antitrust laws has occurred and that his business or property has

Antitrust Reform: The Congressional Prognosis, Trial, Apr. 1979, at 26; Note, supra.

- See text and notes at notes 48-55 infra.

3 Mid-West Paper Prods. Co. v. Continental Group, 596 F.2d 573 (3d Cir. 1979); Lefrak v. Arabian Am. Oil Co., 947 Antrtrust \& Trade RzG. REP. (BNA) A-1 (E.D.N.Y. Jan. 10, 1980); International Ass'n of Machinists v. OPEC, 932 ANTITrust \& Trade Reg. Rep. (BNA) E-1 (C.D. Cal. Sept. 18, 1979).

s "One which fixes the amount to be paid the contractor on a basis, generally, of the cost of the material and labor, plus an agreed percentage thereof as profits. Such contracts are used when costs of production or construction are unknown or difficult to ascertain in advance." Black's Law Dictronary 312 (5th ed. 1979).

- E.g., Eastern Air Lines, Inc. v. Atlantic Richfield Co., 609 F.2d 497 (Temp. Emer. Ct. App. 1979) (dictum); Phillips v. Crown Cent. Petroleum Corp., 602 F.2d 616 (4th Cir. 1979) (dictum); In re Beef Indus. Antitrust Litigation, 600 F.2d 1148 (5th Cir. 1979).

10 There is a third approach to the problem: arguing that the policies advanced by the Supreme Court in support of the no-pass-on rule are misguided, and that the exception should therefore be liberally construed. Such an approach amounts to an attack on the rule itself, and is beyond the scope of this comment. For an introduction to the debate on the rule itself, see authorities cited note 5 supra. 
been injured thereby.11 Normally, a plaintiff overcharged by the defendant as a result of price fixing or some other antitrust violation has made out a prima facie case for recovery. ${ }^{12}$

The pass-on theory is shorthand for the not implausible notion that the party entitled to sue for such an overcharge is the one at the end of a distribution chain. Assume that an antitrust violator imposes an illegal overcharge on its customer, the direct purchaser. ${ }^{13}$ If that customer is not at the end of the distribution chain, often it will not absorb the overcharge. Instead, it will act as a conduit for the overcharge, adding it to the resale price and passing it on to its own customer, the indirect purchaser. If the direct purchaser succeeds in passing on the overcharge, it has not suffered any harm, and hence it has no right to recover under section 4 of the Clayton Act. ${ }^{14}$ Prior to Hanover Shoe, this theory, known as defensive pass-on, was available to antitrust violators in their attempts to defeat direct purchasers' section 4 actions.

On the other hand, the indirect purchaser at the end of the distribution chain has been injured within the meaning of the Act. The overcharge has been passed on to it, and it is incapable of passing the overcharge on any further. Therefore, prior to Illinois Brick, indirect purchasers could rely on offensive pass-on theory to justify recovery from the original price-fixer.

Despite its initial appeal, this reasoning founders when confronted with economic theory. It is extremely unusual for a direct purchaser to be able to pass on the entire overcharge to its own customers. ${ }^{15}$ The degree to which an overcharge is passed on is theoretically calculable by a formula developed in the branch of economics known as incidence theory. ${ }^{16}$ The amount of pass-on is de-

1115 U.S.C. $\$ 15$ (1976); see Pollock, Automatic Treble Damages and the Passing-On Defense: The Hanover Shoe Decision, 13 ANTITRust BuLl. 1183, 1184-85 (1968).

12 See Pollock, supra note 11, at 1185.

1s Id. at 1186-87. Although pass-on could be repeated for many levels in a distribution chain, for simplicity's sake this analysis will assume a single level of indirect purchasers. The various complexity arguments discussed in this comment would have even more force in a multilevel context.

it See id. at 1186.

1s See, e.g., Cirace, Price-Fixing, Privity and the Pass-On Problem in Antitrust TrebleDamages Suits: A Suggested Solution, 19 WM. \& MARY L. REv. 171, 181-83 (1977); Schaefer, Passing-On Theory in Antitrust Treble Damage Actions: An Economic and Legal Analysis, 16 WM. \& MARY L. Rev. 883, 887-89 (1975).

16 This theory, originally developed to analyze the impact of taxes, see R. MUSGrave \& P. Musgrave, Public Finance in Theory and Practice 375-403 (2d ed. 1976); P. SamuelsON, Economics 389-90 (10th ed. 1976), generally has been accepted as the best theoretical tool for analyzing the impact of an overcharge. See, e.g., Illinois Brick Co. v. Ilinois, 431 
pendent on the relative elasticities ${ }^{17}$ of supply and demand for the direct purchaser's product. ${ }^{18}$

"Elasticity" is a measure of the amount of change in quantity supplied or demanded in response to a change in price. The more inelastic-or unresponsive to changes in price-the demand, and the more elastic-or responsive to changes in price-the supply, the larger the share of any overcharge imposed on the direct purchaser (seller) that can be shifted to the indirect purchaser (buyer). Conversely, the more elastic the demand, and the more inelastic the supply, the greater the share of an overcharge the direct purchaser (seller) must bear himself. Only in the extreme situations where demand is either perfectly elastic or perfectly inelastic does either party bear the entire burden.18 Where demand is perfectly inelastic, the indirect purchaser (buyer) absorbs the entire overcharge; where demand is perfectly elastic, the direct purchaser (seller) absorbs it. ${ }^{20}$ In all intermediate cases, the overcharge is apportioned between them. ${ }^{21}$

U.S. 720, 741 \& n.25 (1977); Cirace, supra note 15, at 180-82; Harris \& Sullivan, supra note 5, at 275-76; Schaefer, supra note 15, at 883, 915-16. For a compact development of an apportionment formula in the pass-on context, see Landes \& Posner, supra note 5, at 61518. This discussion will focus on the effects of an overcharge, but incidence theory is equally applicable to any increase in the seller's costs.

${ }^{17}$ Elasticities of supply and demand are defined as the percentage change in the quantity supplied or demanded resulting from each one percent change in price. See, e.g., E. Mansfietd, Microeconomics 24-30 (3d ed. 1979); P. SAMUELSON, supra note 16, at 381-88. The discussion which follows is based on the authorities cited in notes 15 and 16 supra.

${ }^{18}$ That is, the indirect purchaser and the middleman (the direct purchaser) will share the overcharge in the ratio

$$
\frac{\text { buyer's burden }}{\text { seller's burden }}=\frac{\text { elasticity of supply }}{\text { elasticity of demand }}
$$

See Illinois Brick Co. v. Illinois, 431 U.S. 720, 741 (1977); R. Musgrave \& P. Musgrave, supra note 16, at 446 n.12; P. SAMUzLson, supra note 16, at 387-88; Schaefer, supra note 15, at 893.

10 Demand for a good is said to be perfectly or completely elastic when an effectively unlimited amount will be demanded at a certain price, but nothing will be demanded at any higher price. Perfect, complete, or infinite inelasticity of demand means that the quantity demanded remains constant despite changes in price. See P. Samuelson, supra note 16, at 385-86.

${ }^{30}$ This analysis of a monopoly overcharge can be turned around to determine whether the indirect seller or the middleman bears the brunt of artificially low prices when buyers exert monopsony power. If supply is perfectly inelastic, so that the seller will supply a constant quantity even though prices fall, the seller bears the entire burden. If supply is perfectly elastic, so that the seller will furnish an unlimited quantity at a given price but nothing at all at any lower price, the burden falls entirely on the middleman. See text and notes at notes 26-28 infra.

21 A similar analysis applies when supply is either perfectly elastic or perfectly inelastic, except that perfect inelasticity results in the direct purchaser (seller) absorbing the entire 
FIGURE 1

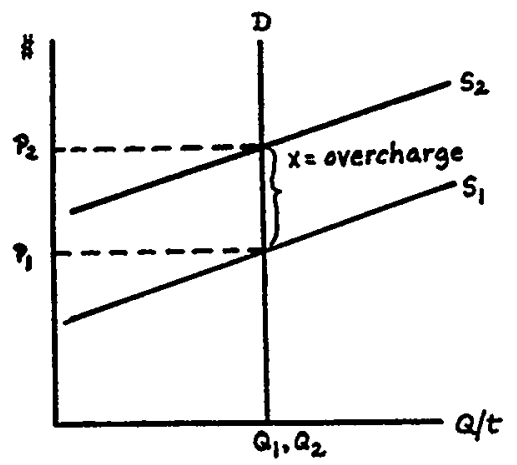

FIGURE 2

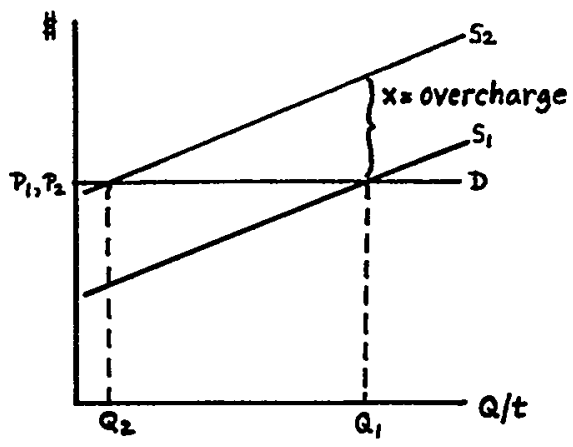

FIGURE 3

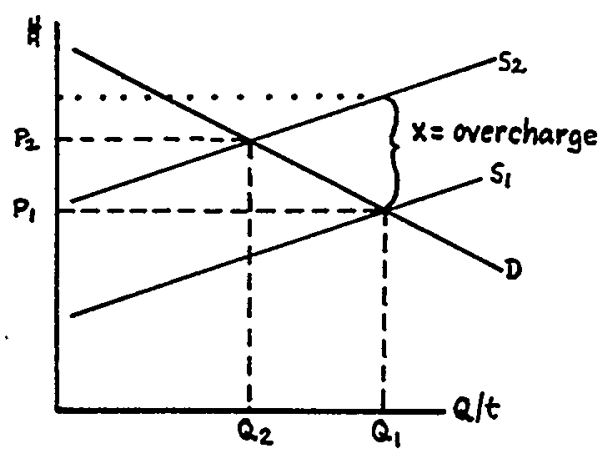

overcharge, while perfect elasticity places the overcharge on the indirect purchaser (buyer). See Schaefer, supra note 15, at 887-97. 
Figures 1 and 2 illustrate the extreme situations. ${ }^{22}$ In Figure 1 a typical upward sloping supply curve $e^{23}$ and a perfectly inelastic demand are assumed. Inasmuch as the supply curve for the seller's industry is determined by the industry's costs, ${ }^{24}$ the imposition of an overcharge $(x)$ on the industry will raise those costs by $x$ and shift the entire supply curve by $x$, from $S_{1}$ to $S_{2}$. Because the quantity and price of the good are determined by the intersection of the supply and demand curves, ${ }^{25}$ the price will increase by $x$ from $\mathrm{P}_{1}$ to $P_{2}$ while the quantity remains constant. Hence, the entire overcharge will be borne by the buyer. In Figure 2, the overcharge has the same effect on the supply curve of the seller's industry, shifting it from $S_{1}$ to $S_{2}$, but demand is assumed to be perfectly elastic. Buyers will not pay more than $P_{1}$, and the seller must either absorb the entire overcharge himself or suffer a drastic loss of sales. ${ }^{26}$ In the typical market, however, the demand curve is neither

22 For a thorough discussion of the following material, see id.

2s See, e.g., E. MANSFIELd, supra note 17, at 27; P. SAMUELSON, supra note 16, at 62-63.

14 More precisely, the supply curve of the single competitive firm is determined by the costs of additional units of output (marginal costs) above a break-even point. The supply. curve of an industry is the horizontal summation of the supply curves of individual firms in the industry. See, e.g., E. MANSpIELD, supra note 17, at 253-55; P. SAMUELSON, supra note 16 , at $451-57$. 68.

${ }^{18}$ See, e.g., E. MANSFIELd, supra note 17, at 31-33; P. SAMUELSON, supra note 16, at 63-

${ }^{26}$ In the inverse situation, where the monopsonist has the ability to force price down instead of the monopolist's being able to force price up, the middleman can make the seller absorb the entire loss where supply is perfectly inelastic (Figure A) and must take the whole loss himself where supply is perfectly elastic (Figure B). The drop in price is apportioned in Figure C, see note 28 infra.

\section{FIGURE A}

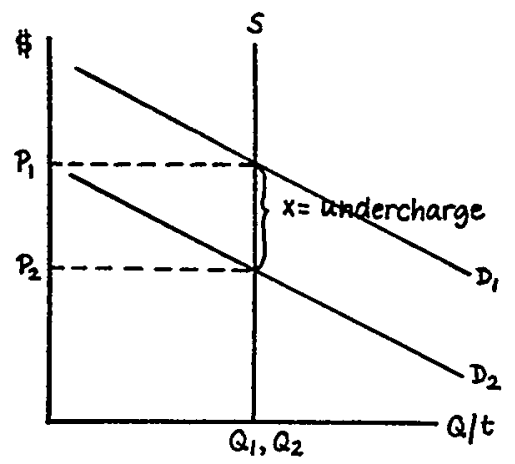


perfectly elastic nor perfectly inelastic: it slopes downward. ${ }^{27}$ The effects of an overcharge in such a market can be seen in Figure 3. An overcharge of $x$ still raises the supply curve by $x$. But because the demand curve is downward sloping, the new supply curve intersects it to the left of and above the original equilibrium point. The seller can raise his price, but the buyer will demand a smaller quantity of goods. How much of the overcharge the seller can recoup and how much the quantity of goods sold will decline depends on the relative elasticities of supply and demand. In the usual market the overcharge will be partially borne by both the buyer and the seller. ${ }^{28}$ In the antitrust vocabulary, therefore, both

FIGURE B

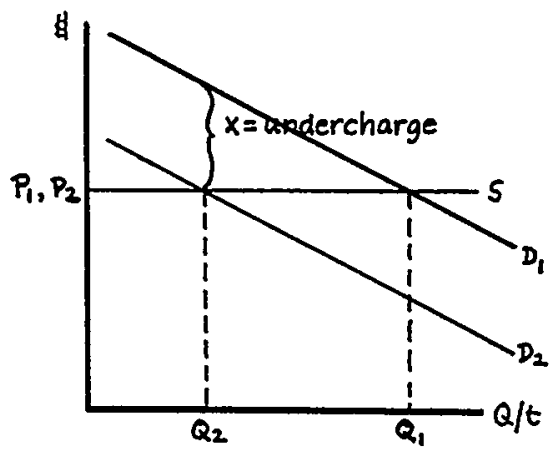

FIGURE C

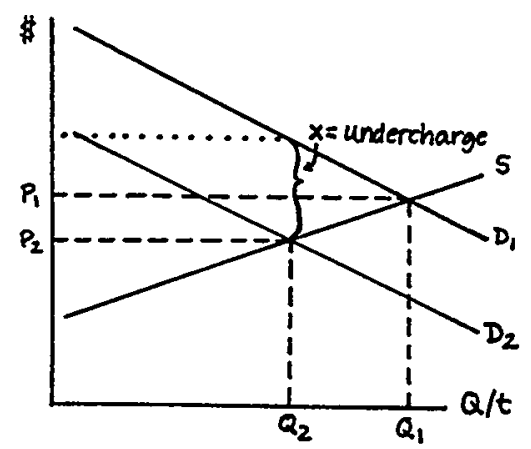

27 See, e.g., E. MANSFIELD, supra note 17, at 20; P. SAMUELSON, supra note 16, at 60-62.

28 In the typical market the supply curve slopes upward. See, e.g., E. MaNSFIELD, supra note 17 , at 27 ; P. SAMUELson, supra note 16 , at $62-63$. Where a monopsony depresses price, the supply curve intersects the shifted demand curve to the left of and below the old equilibrium point. The middleman can pass on the lowered price, but the seller will limit his output at that price; both buyer and seller will bear some part of the loss. See Figure C, 
the direct purchaser and the indirect purchaser will pay part of the price fixer's overcharge, and both can claim to have sustained injury within the meaning of section 4 of the Clayton Act. ${ }^{29}$

\section{B. The Rule Against Pass-On}

For many years, Clayton Act defendants asserted pass-on as a defense against actions by direct purchasers. ${ }^{30}$ The Hanover Shoe decision put an end to this defensive use of pass-on. The Court stressed three grounds for its decision. First, any illegal overcharge was prima facie an injury to the direct purchaser. How the effects of this injury might be mitigated was a separate question. ${ }^{31}$ Second, if pass-on blocked the direct purchaser's suit, the right to recover had to belong to indirect purchasers. But if such purchasers were numerous, any recovery would be divided, thus reducing the incentive for any one potential plaintiff to sue and detracting from the policy of encouraging private enforcement of the antitrust laws. ${ }^{32}$ Finally, the problems of proof associated with pass-on seemed immense: unless the defense were rejected, the judicial system might not be able to handle antitrust litigation. ${ }^{33}$ The Justices $^{34}$ stated that pass-on had to be complete in order to negate any possibility of injury to the direct purchaser. Proof of complete pass-on would require a showing that the overcharge had no effect at all on the direct purchaser's actual or potential profits per unit of sales volume. ${ }^{35}$ Such a showing would be practically impossible, because the effects of an overcharge are "virtually unascertainable"38 in the real world. Nonetheless, many defendants could be expected to assert the defense if it were available, bolstering it

note 26 supra.

${ }^{20}$ See text and notes at notes 11-12 supra.

so See Pollock, supra note 11, at 1191, and cases cited therein.

${ }^{31}$ Hanover Shoe, Inc. v. United Shoe Mach. Corp., 392 U.S. 481, 489-91, 494 (1968). But see Pollock, supra note 11, at 1207-08.

32392 U.S. at 494.

ss Id. at 491-93.

s4 Only Justice Stewart disagreed. He dissented on the grounds that no antitrust violation had been proved and therefore did not reach the pass-on issue. Id. at $\mathbf{5 1 0}$.

so This is consistent with the incidence theory analysis, see text and notes at notes 1529 supra. If the overcharge is not completely passed on, that theory would predict both lost sales and a drop in profits per unit. The supply and demand curves intersect to the left of the competitive equilibrium point, representing a lesser quantity, and at a new price which has not increased as much as the direct purchaser's costs. See Figure 3 supra.

so 392 U.S. at 493. 
with "massive evidence and complicated theories"st and consuming scarce judicial resources in futile arguments. ${ }^{88}$

Subsequent lower court decisions split over whether Hanover Shoe's rationale also barred offensive pass-on..$^{38}$ Ultimately, Illinois Brick established that offensive use of the theory was likewise forbidden. The majority in this six-to-three decision found that Hanover Shoe's ratio decidendi was the concern with the complexities of proof in defensive pass-on. ${ }^{40}$ Such complexity was at least as likely in offensive pass-on. ${ }^{11}$ Inasmuch as the majority found Hanover Shoe's concern with complexity valid and controlling, offensive pass-on had to be rejected. ${ }^{42}$ Use of offensive pass-on would convert treble damage actions into efforts to apportion damages among all possible plaintiffs. Attempted apportionment, in turn, would complicate section 4 suits to an impractical and unacceptable extent.43

The majority adverted to incidence theory as a possible means of apportioning an overcharge between direct and indirect purchasers. ${ }^{44}$ It found the theoretical formula unhelpful in concrete situations, however: the elasticities that the formula requires are difficult to measure, and the judicial system is not equipped to handle "sophisticated statistical methodology."45 Furthermore, the

${ }^{37} I d$.

se Id. at $491-93$.

30 Compare Mangano v. American Radiator \& Standard Sanitary Corp., 438 F.2d 1187 (3d Cir. 1971) (per curiam) (alternate holding that offensive pass-on is barred) with In re Western Liquid Asphalt Cases, 487 F.2d 191 (9th Cir. 1973) (offensive pass-on not barred after Hanover Shoe), cert. denied, 415 U.S. 919 (1974). These cases, especially Mangano, inspired a considerable amount of academic comment. See, e.g., Beane, Antitrust: Standing and Passing-On, 26 BAyLor L. REv. 331 (1974); Note, The Effect of Hanover Shoe on the Offensive Use of the Passing-On Doctrine, 46 S. CaL. L. REv. 98 (1972).

to Illinois Brick Co. v. Illinois, 431 U.S. 720, 732-33 (1977).

11 Id. at 732-33, 737-41. The possibility of additional complexity arises from the potential use of offensive pass-on by an indirect purchaser with more than one middleman between it and the antitrust violator. Such use would require proof of complete pass-on at every level of the distribution chain, whereas defensive use of pass-on doctrine against the direct purchaser requires such proof at only one level. Id.

4I Id. at 736-47. Justice Brennan's dissent stressed the encouragement-of-privateenforcement rationale of Hanover Shoe and concluded that that goal, coupled with the compensatory aims of the Clayton Act, required that offensive pass-on be allowed. Id. at 748-50 (Brennan, J., dissenting).

is $\mathrm{Id}$. at 736-47. This reasoning is also the implicit explanation for the requirement in Hanover Shoe that the pass-on proponent completely disprove all possible harm to the direct purchaser. See text and notes at notes 93-98 infra.

"4 431 U.S. at 741. See text and note at note 18 supra.

65 431 U.S. at 742. For a discussion of the difficulty of measuring actual elasticities, see Landes \& Posner, supra note 5, at 619-20. The main reasons are (1) that it is almost impos- 
majority was unwilling to give credence to the "array of simplifying assumptions" on which the formula rests-that an overcharge is evenly imposed on all direct purchasers, and that each direct purchaser is rationally maximizing profits in a perfectly competitive market. ${ }^{46}$ Thus it seems that, even if elasticities were conveniently measurable and statistical expertise readily available in litigation, the Court would be reluctant to trust the theory. ${ }^{47}$

\section{The Exception to the Rule Against Pass-On}

The factors that led the Hanover Shoe Court to bar defensive pass-on also led it to create an exception, of uncertain dimensions, where those factors were not paramount. The Court recognized that "there might be situations-for instance, when an overcharged buyer has a pre-existing 'cost-plus' contract, thus making it easy to prove that he has not been damaged-where the considerations requiring that the passing-on defense not be permitted in this case would not be present."48 The opinion gave no guidance about what specific fact situations were contemplated. The use of the word "might" left open contradictory possibilities: that the preexisting, cost-plus contract was merely illustrative, or that the Court had doubts that even such a contract warranted the use of pass-on.

The Illinois Brick opinion clarified matters. It interpreted the Hanover Shoe dictum as intended to create a narrow exception.98 Further, because it read Hanover Shoe as concerned primarily with proof and apportionment problems, it focused on how the cost-plus contract avoided these difficulties. ${ }^{50}$ Under a preexisting, fixed-quantity, cost-plus contract, the effect of an overcharge is predetermined. ${ }^{\text {sI }}$ The overcharge is just another of the direct pur-

sible to find both supply and demand elasticity for the same product, because the easiest way to find either is to hold the other fixed; and (2) that elasticities vary over time and at different points along the supply and demand curves. Furthermore, in any situation involving a multilevel chain of distribution, the calculations must be performed anew for each level. For the contrary opinion, asserting that it would be possible to prove elasticities in litigation, see Schaefer, supra note 15, at 915-16.

43 U.S. at 741-43.

42 Id. at $742-43$.

48 Hanover Shoe, Inc. v. United Shoe Mach. Corp., 392 U.S. 481, 494 (1968).

40 Illinois Brick Co. v. Illinois, 431 U.S. 720, 735-36 (1977). The Court reached this conclusion because Hanover Shoe provided only the single example of the preexisting costplus contract to illustrate the exception.

so Id. at 732 n.12, 735-36.

si Id. at 736 . 
chaser's costs, which the indirect purchaser is committed to pay. Moreover, "the [direct] purchaser is insulated from any decrease in its sales . . . because its customer is committed to buying a fixed quantity regardless of price." The contract thus "circumvent[s] complex market interactions"ss of supply and demand that normally make it impossible to trace the effects of an overcharge. The contract makes it "easy to prove" that the direct purchaser did not absorb any of the overcharge and hence was not damaged. ${ }^{.4}$

There are therefore no proof or apportionment problems-and thus there is no reason to prohibit either offensive or defensive pass-on-when the transactions on which an antitrust suit is based occur under a preexisting, fixed-quantity, cost-plus contract. Defensively, the antitrust defendant can counter a direct purchaser's suit by showing that all the plaintiff's business was conducted under such contracts with subsequent customers. Offensively, the indirect purchaser can show conclusively that the burden of the antitrust violation has fallen on him, rather than on the direct purchaser. In fact, unless the indirect purchaser can sue, the antitrust violator will retain the fruits of his illegal conduct for lack of a compensable victim. Such a result is contrary to the often enunciated policies of encouraging "private attorneys general" to enforce the antitrust laws and of achieving deterrence of future violations through the treble-damage sanctions. ${ }^{\text {ss }}$

- What is most notable about the Illinois Brick Court's interpretation of the exception is that, despite the Court's aversion to incidence theory and its underlying assumptions, the preexisting, fixed-quantity, cost-plus contract is exactly like the perfectly inelastic demand situation illustrated in Figure 1. If the contract is made before the imposition of the overcharge, neither the buyer nor the seller can be responding to the antitrust violation in setting contract terms. If it is made for a fixed quantity, the buyer cannot renegotiate the quantity he will take after the overcharge is imposed, thus shifting some of the loss to the seller. Also, if the buyer has agreed to accept all the seller's risk of increased costs in order to guarantee a given quantity of goods, the seller need not absorb

82 Id.

ss Id.

s. Id. at 732 n.12 (quoting Hanover Shoe, Inc. v. United Shoe Mach. Corp., 392 U.S. 481, 494 (1968)).

so See, e.g., Ilinois Brick Co. v. Illinois, 431 U.S. 720, 745-46 (1977); Hanover Shoe, Inc. v. United Shoe Mach. Corp., 392 U.S. 481, 494 (1968); Landes \& Posner, supra note 5, at $605,608-09$. 
any of the overcharge himself to meet the contract's price terms.

\section{Conflicting Treatment of the Cost-Plus Exception}

There have been two conflicting responses to the creation of the cost-plus exception by Hanover Shoe. One maintains that only an actual contract will suffice to bring a transaction within the exception. The other is willing to accept the "functional equivalent" of such a contract.

\section{A. The Literal Interpretation}

Several opinions written between Hanover Shoe and Illinois Brick concluded that only an actual cost-plus contract triggered the exception. ${ }^{56}$ The major post-Illinois Brick case to take this literal view of the exception is Mid-West Paper Products Co. v. Continental Group, Inc. ${ }^{57}$ In one of the actions consolidated there, the plaintiffs were supermarket and retail grocery owners who purchased goods already packaged in price-fixed "consumer bags" manufactured by the defendants. The Third Circuit, on the strength of Illinois Brick, affirmed a summary judgment against these indirect purchasers despite their pleas that informal week-toweek arrangements to buy varying quantities on a cost-plus basis were sufficient to invoke the Illinois Brick exception. ${ }^{58}$

B6 See, e.g., Mangano v. American Radiator \& Standard Sanitary Corp., 438 F.2d 1187 (3d Cir. 1971); Bill Minnielli Cement Contracting, Inc. v. Richter Concrete Corp., 1973-1 Trade Cas. 94,611 (S.D. Ohio 1973); Balmac, Inc. v. American Metal Prods. Corp., 1972 Trade Cas. 93,061 (N.D. Cal. 1972). The most thorough of these pre-Illinois Brick opinions was Yoder Bros., Inc. v. California-Florida Plant Corp., 537 F.2d 1347 (5th Cir. 1976), cert. denied, 429 U.S. 1094 (1977). In the course of a long, complex opinion, the court, citing Hanover Shoe, held that the exception was available only if the pass-on proponent carried the "almost insuperable" burden of disproving any effect of the overcharge on the direct purchaser. To do so, the proponent would have to show that the direct purchaser raised its prices by the amount of, and solely because of, the overcharge, without any adverse effects on sales volume, as well as disprove the possibility of such an increase in the absence of an overcharge. Furthermore, this showing would have to be made without the complex economic evidence that had disturbed the Hanover Shoe Court. Id. at 1375-76. The only method of proof that met these criteria, the Yoder court concluded, was the literal cost-plus contract, for which

[t]wo characteristics are essential . . . : first, the buyer must have his contract with a particular customer for a particular sale before the illegal overcharge is imposed on the buyer, and second, the contractual arrangement must assure that whatever the cost of the product was to the buyer, it is the same to the customer.

Id. at 1376 .

s7 596 F.2d 573 (3d Cir. 1979).

ss Id. at 580 . 
The Paper Products court stated that Hanover Shoe and Illinois Brick barred the use of the pass-on theory except "in the limited circumstances when tracing the interaction of market forces is unnecessary." "69 The court regarded it as established by Illinois Brick that an indirect purchaser could utilize offensive pass-on only if it could demonstrate that it had absorbed the entire overcharge. That demonstration in turn would require proof that all intermediary purchasers were insulated from the overcharge by preexisting, fixed-quantity, cost-plus contracts. ${ }^{60}$

Two district courts ${ }^{\mathrm{et}}$ subsequently have reached the same conclusion. Both rejected asserted analogues of preexisting, fixedquantity, cost-plus contracts as insufficient to justify the use of pass-on. In each case, the court found that proof of pass-on was not allowed unless the evidentiary complexities associated with proving complete pass-on were overcome. Only an actual preexisting, fixed-quantity, cost-plus contract met this exacting criterion. ${ }^{82}$

s9 Id. at 577 .

so Id. at 578 .

-1 International Ass'n of Machinists v. OPEC, 932 Antitrust \& Trade Reg. Rep. (BNA) E-1 (C.D. Cal. Sept. 18, 1979), was a suit brought against the oil-producing cartel (which was insulated by a series of middlemen) on behalf of the ultimate buyer of gasoline. The court granted summary judgment for the defendants, citing Illinois Brick as one of its reasons. Lefrak v. Arabian Am. Oil Co., 947 Antitrust \& Trade Reg. Rep. (BNA) A-1 (E.D.N.Y. Jan. 10, 1980), involved a claim by landlords that the oil companies were engaged in price fixing. That claim ran into an "Illinois Brick wall" and was dismissed on a motion for summary judgment because of the presence of independent middlemen in the distribution chain. because

2 In $O P E C$, the court stated that such a contract justified use of pass-on doctrine

[t]he interaction of supply and demand would not complicate the damage determination in such a situation since the indirect purchaser would be tied to a fixed quantity with the overcharge being directly passed on ....

The two primary features of the cost-plus contract which led the Court to cite this as a possible exception to Illinois Brick are: (1) a direct and easily measurable pass-on of costs, and (2) a commitment for a fixed quantity precluding evidentiary complexities due to considerations of decreasing sales.

International Ass'n of Machinists v. OPEC, 932 AntrTrust \& Trade Reg. Rep. (BNA) E-1, E-4 (C.D. Cal. Sept. 18, 1979). The federal statutes allowing middlemen to pass on increases in the price of oil were insufficient to bring the case within the cost-plus exception because the pass-on was discretionary rather than automatic and the quantity was not fixed. The situation was therefore not analogous to a "true cost-plus contract." Id.

The Lefrak court ruled that a requirements contract with prices indexed to the distributors' costs was insufficient to invoke the exception. Because the indirect purchaser was found to have the market power to negotiate the price down, and was not bound to accept a certain quantity, the contract did not satisfy what the court held were the three requirements of the cost-plus exception: that pass-on be automatic and complete, that there be no possibility of decline in sales volume, and "that a contract exists which commits the indirect 


\section{B. The Functional Interpretation}

During the period between Hanover Shoe and Illinois Brick, many courts asserted that anything "similar" or "analogous" to a preexisting, fixed-quantity, cost-plus contract justified the use of the Hanover Shoe exception by making pass-on easy to prove. ${ }^{63}$ This theory was specifically rejected by Illinois Brick, ${ }^{84}$ and the cases employing it were overruled. Despite this unfavorable background, Judge Wisdom, writing for a unanimous panel in In re Beef Industry Antitrust Litigation, ${ }^{88}$ reversed a dismissal for failure to state a claim and held that the "functional equivalent" of a preexisting, fixed-quantity, cost-plus contract came within the cost-plus exception. ${ }^{86}$

purchaser to buying a fixed quantity regardless of price." Lefrak v. Arabian Am. Oil Co., 947 Antitrust \& Trade Reg. ReP. (BNA) A-1, A-1 (E.D.N.Y. Jan. 10, 1980).

es See, e.g., Standard Indus., Inc. v. Mobil Oil Corp., 475 F.2d 220 (10th Cir. 1973) (dictum that passing-on defense is available when there is cost-plus contract or where middleman buys and resells a product in unchanged form); West Virginia v. Chas. Pfizer \& Co., $440 \mathrm{~F} .2 \mathrm{~d} 1079$ (2d Cir. 1971) (wholesalers and retailers allowed to retain $\$ 3$ million settlement despite evidence that drug overcharges were passed on to consumers), cert. denied, 404 U.S. 871 (1974); Minnesota v. United States Steel Corp., 438 F.2d 1380 (8th Cir. 1971) (plaintiffs ordered to answer interrogatories about extent to which overcharges on structural steel were passed on to federal government which funded $90 \%$ of interstate highway construction program); Obron v. Union Camp Corp., 355 F. Supp. 902 (E.D. Mich. 1972) (defensive pass-on allowed against plaintiff who bought window bags at list price minus $5 \%$ and resold at list price), aff'd per curiam, 477 F.2d 542 (6th Cir. 1973); In re Master Key Antitrust Litigation, 1973-2 Trade Cas. 94,977 (D. Conn. 1973) (relationship between hardware supplier, building contractors, and purchasers of buildings possible functional equivalent of cost-plus contract); Donson Stores, Inc. v. American Bakeries Corp., 58 F.R.D. 481 (S.D.N.Y. 1973) (consumer intervenors have no standing to sue in absence of allegations of cost-plus contract or analogous fixed-price markup); Denver v. American Oil Co., 53 F.R.D. 620 (D. Colo. 1971) (where overcharges for asphalt included in contractor's general bid, no cost-plus analogy available as basis for class action).

64 431 U.S. at 743-45. See text and notes at notes 109-110 infra.

${ }^{65} 600$ F.2d 1148 (5th Cir. 1979). The decision relied heavily on suggestions made in two law review notes. Id. at 1163-64 (citing Note, Scaling the Illinois Brick Wall: The Future of Indirect Purchasers in Antitrust Litigation, 63 ConNell L. REv. 309 (1978) [hereinafter cited as Note, Scaling the Illinois Brick Wall]; Note, Recovery by Indirect Purchasers and the Functions of Antitrust Treble Damages, 55 Tex. L. REv. 1445 (1978) [hereinafter cited as Note, Recovery by Indirect Purchasers]).

s8 600 F.2d at 1166-67. In so holding, the court had to explain away, id. at 1164 n.20, its own prior holding in Yoder Bros., Inc. v. California-Florida Plant Corp., 537 F.2d 1347 (5th Cir. 1976), cert. denied, 429 U.S. 1094 (1977), which required an actual contract with a fixed-quantity provision in order to preclude the possibility of losses in volume. The Beef Industry court argued that Yoder was based on the concern expressed in Hanover Shoe with encouraging private attorneys general. Inasmuch as the Illinois Brick Court substituted for that rationale one based on the complexity of proof involved in pass-on, the Yoder decision was no longer valid. This effort to avoid Yoder is specious: the earlier court, like the Supreme Court, was concerned mainly with complexity of proof. See note 56 supra. 
Beef Industry was a monopsony case, involving the passing on of an artificially low price, rather than an overcharge. ${ }^{67}$ The allegation was that retailers had conspired to depress the price of beef, that they had imposed the lower price on their suppliers, and that the suppliers in turn had forced cattlemen to accept it. The plaintiff cattlemen argued that complete pass-on of the low price was possible, for two reasons. First, the price paid to cattlemen was arrived at by an allegedly rigid, formulaic calculation from the retailers' price, analogous to a cost-plus term. Second, cattle kept in feed lots for a certain period of time had to be brought to market, whatever the price conditions. The fact that the supply of beef cattle was highly inelastic, the plaintiffs maintained, was analogous to the fixed-quantity term of an Illinois Brick-Hanover Shoe contract.

The Beef Industry court recognized that Illinois Brick is the controlling precedent for monopsony as well as monopoly cases. ${ }^{68}$ Judge Wisdom interpreted Hanover Shoe as having created "a general exception to the bar against assertion of a passing-on defense, an exception defined by the policies underlying the bar." ${ }^{89}$ These policies were a desire to avoid unclear and unreliable evidence and the concomitant risk of multiple liability. ${ }^{70}$ Judge Wisdom attributed the refinement of the exception in Illinois Brick to the Justices' concern with speculative evidence and with multiple liability resulting from different interpretations of that evidence. ${ }^{71}$ He therefore concluded that, if the allegations of inelasticity and rigid formula-based pricing were true, the effect of the price-fixing by beef retailers would be determinable "in advance without re-

or See the analysis of monopsony at note 20 supra, and Figure A, which illustrates the plaintiffs' contentions, at note 26 supra. The fallacy in the plaintiffs' argument is discussed in text at notes 107-109 infra.

600 F.2d at 1157-59.

Id. at 1163.

70 Id.

${ }^{71}$ Id. at 1163 \& n.19. Judge Wisdom misreads Illinois Brick. The Supreme Court was not worried about multiple liability arising from ambiguous evidence. It was concerned that if it did not bar offensive pass-on and create symmetry with Hanover Shoe, pass-on would be asserted by indirect purchasers, but could not be used against direct purchasers. The result could be an antitrust defendant held liable to both indirect and direct purchasers for treble damages for the same overcharge. Illinois Brick Co. v. Illinois, 431 U.S. 720, 729-36 (1977). Furthermore, the speculative nature of economic evidence was the Court's specific objection to incidence theory, $i d$. at 741-42, but this does not support the negative inference that "[ $t$ ]he Court was concerned not so much with the complexity of such proof as with its speculative character," In re Beef Indus. Antitrust Litigation, 600 F.2d 1141, 1163 n.19 (1979). 
gard to the interactions of supply and demand." nation in advance was the Supreme Court's justification for the exception, ${ }^{73}$ the functional equivalent of a preexisting, fixed-quantity, cost-plus contract must fall within it. The plaintiffs should at least have the opportunity to prove their allegations. ${ }^{74}$

There is, then, a fundamental conflict in regard to the scope of the exception to the no-pass-on rule. The literalist analysis regards the prohibition of pass-on theory as a result of the inherent complexity and essential impossibility of proving the effect of an overcharge on a direct purchaser's pricing decisions and sales volume in the absence of a preexisting, fixed-quantity, cost-plus contract. The functionalist doctrine focuses on the speculative nature of the usual economic evidence, and would allow use of pass-on theory in those situations in which uncertainty can be avoided. ${ }^{76}$

\section{The Supreme Court and Functional Equivalence}

The argument that the functional equivalent of a preexisting, fixed-quantity, cost-plus contract should lie outside the per se rule against pass-on is initially attractive. After all, a true functional equivalent would by definition provide complete pass-on and avoid the problems of apportionment. Furthermore, the language of the Court does not restrict the exception to actual cost-plus contracts, ${ }^{76}$ although that would have been easy to do explicitly; one can draw the negative inference. that the Court wished to leave the

72600 F.2d at 1165.

73 Illinois Brick Co. v. Illinois, 431 U.S. 720, 736 (1977).

74600 F.2d at 1164, 1166-67.

${ }^{76}$ The Beef Industry reasoning has had its attractions for other courts. In Eastern Air Lines, Inc. v. Atlantic Richfield Co., 609 F.2d 497 (Temp. Emer. Ct. App. 1979), the fuel supplier attempted to assert defensive pass-on because the Civil Aeronautics Board had allowed Eastern to include the higher cost of fuel in its fare increases. The court accepted the concept of functional equivalence, but found it inapplicable to these facts. The CAB had set the new fares after the imposition of the overcharge and based them on general economic conditions prevailing in the whole airline industry. There was, therefore, nothing to correspond to the preexisting element of the cost-plus exception.

Phillips v. Crown Petroleum Corp., 602 F.2d 616 (4th Cir. 1979), is a more ambiguous case. The text of the opinion seems to accept the functional equivalence theory, $i d$. at 633 , yet a note suggests adherence to the literalist interpretation, $i d$. at $633 \mathrm{n} .4$. In any event, the court did not allow a gasoline wholesaler to use defensive pass-on against plaintiff dealers, where the only evidence to which the wholesaler could point was a fixed relationship between wholesale and retail prices during the price fixing conspiracy itself.

Both Eastern Air Lines and Phillips illustrate how difficult-even futile-it is to allow attempts to prove the economic conditions necessary to create functional equivalence.

${ }^{78}$ See Illinois Brick Co. v. Illinois, 431 U.S. 720, 736 (1977); Hanover Shoe, Inc. v. United Shoe Mach. Corp., 392 U.S. 481, 494 (1968); text and notes at notes 48-53 supra. 
exception open to further expansion. ${ }^{77}$ Yet it seems likely that the Court, if it rules on the functional equivalent doctrine directly, will reject it. This prediction is based on two distinct considerations. First, the response of the Court, when it has dealt with arguably similar contentions, has been negative. Second, the policies underlying Hanover Shoe and Illinois Brick are ill-served by allowing proof of the functional equivalent of a preexisting, fixed-quantity, cost-plus contract.

\section{A. The Supreme Court's Response to Allegations of Functional Equivalence}

In Hanover Shoe, the defendant had specifically argued that it should be able to use the pass-on defense where "economic circumstances were such that the overcharged buyer could only charge his customers a higher price because the price to him was higher."78 Such circumstances "might be present" when an overcharge is imposed equally on all buyers, who in turn face an inelastic demand. ${ }^{79}$ These allegations sound very much like the functional equivalent argument of In re Beef Industry Antitrust Litigation. ${ }^{\mathbf{8 0}}$ Yet the decision rejected this defense and created the general rule against defensive pass-on in response to it. It would be ironic to find that the very fact pattern that led the Court to develop the rule fell within its exception.

Again in Illinois Brick, the Court was confronted with a market that the pass-on proponents argued was equivalent to the costplus exception. The demand for the price-fixed concrete blocks was set by contract specifications before the indirect purchasers even accepted bids $^{\mathbf{8}}$ and hence was inelastic; moreover, the price alleg-

77 One can just as easily infer, however, that what the Illinois Brick Court meant to leave open was not extensions of the cost-plus contract exception, but exceptions of an altogether different kind. For example, "[a]nother situation in which market prices have been superseded and the pass-on defense might be permitted is where the direct purchaser is owned or controlled by the customer." 431 U.S. at 736 n.16. The "owned or controlled" exception is rich in ambiguities of its own. See, e.g., Note, Scaling the Illinois Brick Wall, supra note 66, at 328-29 \& nn.85-86; Note, Recovery by Indirect Purchasers, supra note 65, at 1456-57. It suggests, however, that, where the rule against pass-on leads to undesirable results, the solution may be new exceptions, rather than procrustean manipulations of the cost-plus exception.

${ }_{78}$ Hanover Shoe, Inc. v. United Shoe Mach. Corp., 392 U.S. 481, 492-93 (1968) (emphasis in original).

70 Id. at 493.

See text and notes at notes 65-73 supra.

st See Illinois v. Ampress Brick Có., Inc., 536 F.2d 1163, 1164 (7th Cir.), rev'd sub nom. 
edly fully reflected the overcharge because it was set by a rule-ofthumb markup, ${ }^{82}$ similar to the formula pricing alleged in Beef Industry. Invited to stretch the exception to cover these facts, the Court instead used them as the basis for making the bar on offensive pass-on explicit. Again, a situation similar to that which led to the adoption of a rule is unlikely to be found to fall within an exception to that rule.

The Illinois Brick opinion also specifically rejected the earlier lower court cases ${ }^{83}$ that had held that pass-on theory could be used in markets where pass-on would be easy to prove, such as ones in which goods were resold without alteration or for a fixed markup. ${ }^{84}$ The Court refused to "carve out exceptions for particular types of markets"85 in this fashion. Such an attempt would undercut the no-pass-on rule by importing back into the judicial process the same complex evidence the rule was meant to exclude, this time adduced to distinguish between easy and hard-to-prove cases. ${ }^{86}$

At least one of the disapproved cases involved factors like those that persuaded Judge Wisdom to subscribe to the doctrine of functional equivalence in the Beef Industry case. In West Virginia v. Chas. Pfizer \& Co., ${ }^{87}$ the price fixing involved most of the na-

Illinois v. Illinois Brick Co., 431 U.S. 720 (1977). This is an oversimplification, however; if concrete blocks were more expensive than they should be, buildings would be designed using fewer concrete blocks and the direct purchaser would suffer loss of sales volume. Demand would be perfectly inelastic only as to those projects whose specifications were set before the overcharge was imposed. Even as to that limited group, the only potential for pass-on would be in the few cases where overcharge was imposed between the time when the specifications were issued and the time when the bids locking the contractors into a particular price were made. A cost-plus clause in such a contract would provide complete pass-on, but in that case there would be no need to invoke functional equivalence.

${ }^{22}$ Illinois Brick Co. v. Illinois, 431 U.S. 720, 743-44 (1977). See, e.g., Note, Illinois Brick: The Death Knell of Ultimate Consumer Antitrust Suits, 52 ST. JoHN's L. REv. 421, $435 \mathrm{n} .57$ (1978), for the suggestion that the Court should have accepted this situation as analogous to a cost-plus contract because it converted the direct purchasers into mere conduits for the overcharge.

ss Illinois Brick Co. v. Illinois, 431 U.S. 720, 743-45, 743 n.28 (1977). See also text and notes at notes 63-64 supra.

st Beane, supra note 39, at 351, suggested that pass-on should be allowed in situations where "the product reaches [the ultimate purchasers] in the same form as that sold by the overcharging suppliers." The Court seems to have rejected Beane's suggestion. See Illinois Brick Co. v. Illinois, 431 U.S. 720, 743, 744 (1977). Although the effects of an overcharge are harder to trace where the price-fixed product is altered or incorporated into another product, the absence of alteration or incorporation does not make tracing and apportionment unnecessary.

ss 431 U.S. at 744.

Id. at 744-45.

314 F. Supp. 710 (S.D.N.Y. 1970), aff'd, 440 F.2d 1079 (2d Cir. 1971), cert. denied, 
tion's supply of antibiotics. Demand for antibiotics ought to have been highly inelastic, because consumers who buy them need them urgently and because there are few if any acceptable substitutes. In the chain of distribution, conspiring manufacturers sold in dosage form to wholesales; wholesalers resold at cost plus $16.6 \%$ to retailers; and retailers resold, at their cost plus a flat fee or $66.6 \%$, to consumers. ${ }^{88}$ The district court had approved a settlement that gave the lion's share of the damages, $\$ 37$ million, to the consumerplaintiff class; $\$ 3$ million went to the wholesaler and retailer classes to persuade them to accept the settlement. ${ }^{82} \mathrm{On}$ appeal, the Second Circuit rebuffed the wholesaler and retailer plaintiffs' efforts to obtain a larger share of the settlement. ${ }^{90}$ Essentially, the case is one that allows indirect purchasers to use offensive pass-on where demand is highly inelastic and the overcharge is passed on at each level. Yet the Supreme Court disapproved the case in Illinois Brick. ${ }^{91}$

B. The Implications of Functional Equivalence for the Policies Underlying the Rule Against Pass-On

Proponents of functional equivalence must find the Supreme Court's reaction to allegations of functional equivalence in Hanover Shoe, Illinois Brick, and the intervening cases daunting. But functionalists could still argue that the allegations in each case were flawed, and that no case has yet considered true functional equivalence. ${ }^{92}$ It becomes important, therefore, to examine the extent to which even true functional equivalence threatens the policies underlying the no-pass-on rule.

The Supreme Court's basic premise, implicit in Hanover Shoe and explicit in Illinois Brick, ${ }^{\theta 3}$ is that anything less than complete pass-on means that both direct and indirect purchasers have suffered from an antitrust violation. Theoretically, therefore, damages

404 U.S. 871 (1974).

ss 440 F.2d 1079, 1086, 1088 (2d Cir. 1971).

"Id. at 1084 .

1 Id. at 1088.

"I Illinois Brick Co. v. Illinois, 431 U.S. 720, 743 n.28, 744 (1977).

"Thus the Beef Industry court tried to distinguish the case before it from Illinois Brick on the basis of purported formula pricing in the latter and actual formula pricing in the former. In re Beef Indus. Antitrust Litigation, 600 F.2d 1148, 1165 (5th Cir. 1979). The distinction is insubstantial.

ss Illinois Brick Co. v. Illinois, 431 U.S. 720, 737-41 (1977). Cf. Hanover Shoe, Inc. v. United Shoe Mach. Corp., 392 U.S. 481, $492-93$ (1968) (the complexity recognized but apportionment not identified as the main concern). 
should be apportioned between them. Efforts to apportion damages create immense problems of procedure and proof, however; in addition, they vitiate the treble-damages remedy, both as compensation and as deterrence, by increasing the delay and uncertainty of recovery in section 4 actions. The impracticality of apportioning damages necessitates awarding them on an all-or-nothing basis to the party who is the better recipient of the right to recover. Both Hanover Shoe and Illinois Brick identify that party as the direct purchaser.94

Complete pass-on is almost impossible to show. ${ }^{95}$ It requires proof of the "virtually unascertainable" facts that the direct purchaser neither absorbed any of the overcharge nor lost any actual or potential sales volume. Yet attempting to demonstrate complete pass-on would be a common feature of antitrust litigation, ${ }^{97}$ because it would be the only way for an antitrust defendant to defeat, or an indirect purchaser to supplant, the direct purchaser plaintiff. The Court therefore created a per se rule barring attempts to show pass-on, in order to preserve judicial ability to handle antitrust litigation and the integrity of private antitrust

94 In Hanover Shoe the Court appears to have based the selection of the direct purchaser on two factors. First, any overcharge creates a prima facie case of damage to it. 392 U.S. at 489-92. In some cases there would be no indirect purchasers. In others, the indirect purchasers' efforts to prove both the overcharge and the degree of pass-on would involve complex economic evidence and would elicit equally complex efforts by the defendant to disprove pass-on and defeat the indirect-purchaser plaintiffs. It was simpler to give the direct purchaser the right to sue for damages in the first place, because he would end up with it whenever the indirect purchasers failed to carry their burden of proof.

Second, giving the right to recovery to the direct purchaser rather than splitting it among many indirect purchasers ensures a greater incentive for one particular plaintiff to bring suit. Id. at 494 . This theory has attracted considerable criticism: many commentators argue that the direct purchaser is actually less likely to sue than the indirect purchaser because of reluctance to injure its continuing business relationship with the antitrust violator, especially if it has already recovered the overcharge through pass-on to its own customers. See, e.g., Illinois Brick Co. v. Illinois, 431 U.S. 720, 764 (1977) (Brennan, J., dissenting); 10 Conn. L. REv. 447, 462 \& n.76 (1978). The theory does have adherents, however. See, e.g., Landes \& Posner, supra note 5, at 604 \& passim.

The incentive argument explains why defensive pass-on must be prohibited and suits by direct purchasers protected. It does not explain why, once they are in court, indirect purchasers should be barred from using offensive pass-on. In fact, denying all indirect purchasers the right tc sue may reduce the total incentive for private antitrust enforcement by precluding the indirect-purchaser class of plaintiffs. The Illinois Brick majority emphasized the complexity of proof involved in offensive pass-on, see text and notes at notes 41-44 supra, and the need for mutuality to avoid inconsistent judgments, see 431 U.S. at 729-36, as reasons for preferring the direct-purchaser plaintiff.

os Hanover Shoe, Inc. v. United Shoe Mach. Corp., 392 U.S. 481, 491-93 (1968).

- Id. at 491.

${ }^{17}$ Id. at 491-93. 
enforcement.98

The force of the preexisting, fixed-quantity, cost-plus contract exception is that it solves the proof problem, and thereby the apportionment problem. The terms and timing of the contract are readily shown by simple documentary evidence; ${ }^{; 9}$ this showing is a certain indication that the whole overcharge was passed on and that, as to the transactions covered by the contract, the direct purchaser has suffered no loss in volume. ${ }^{100}$

The functional equivalence doctrine does not solve the proof problem, and hence leaves the apportionment problem unresolved. It would allow the pass-on proponent to disprove direct-purchaser harm by showing perfect inelasticity of demand or supply, a dispensation that is tantamount to saying that the proponent should be allowed to use the pass-on theory if it can prove that it is capable of proving pass-on. The complexity the Supreme Court was trying to avoid is simply moved back a step.

This position is untenable. The very core of the pass-on cases is the judgment that not enough pass-on proponents could possibly surmount those proof problems to justify inflicting such complex issues on the courts. Proof of complete pass-on in a functional equivalence case would require either the impossible task of disproving any adverse effect on the direct purchaser with evidence as to sales, prices, and so on, or the use of economic evidence to demonstrate perfect inelasticity and the complete pass-on that such inelasticity entails. But if elasticities could be calculated with the degree of certainty that the functional equivalent argument assumes is possible, the need for a rule against pass-on, or an exception to it, would vanish. ${ }^{101}$ The incidence theory formula, which states that the buyer and the seller bear the burden of an increase in the seller's costs in a proportion equal to the ratio of the elasticity of supply to the elasticity of demand, ${ }^{102}$ would solve apportionment problems with ease. The Supreme Court believed that elasticities could not be calculated reliably, both because of theoretical

18 Illinois Brick Co. v. Illinois, 431 U.S. 720, 745-47 (1977).

20 This is especially true because the Statute of Frauds will require contracts for goods for a price of $\$ 500$ or more to be written or evidenced by written memoranda, U.C.C. $\S 2$ 201.

${ }^{100}$ See text and notes at notes 124-126 infra.

${ }^{101}$ Cf. Illinois Brick Co. v. Illinois, 431 U.S. 720, 741-43 (1977) (rejecting use of incidence theory because of the unreliability of elasticity calculations, but acknowledging the validity of the theory qua theory). See also text and note at note 45 supra.

${ }^{102}$ See text and notes at notes 17-18 supra. 
difficulties ${ }^{103}$ and because actual markets deviate from the competitive model. ${ }^{104}$ It was not unwilling to assume that the incidence theory formula would work if the values to be substituted in it could be ascertained. ${ }^{105}$ The functional equivalent argument misapprehends the Supreme Court's point. ${ }^{108}$ It assumes that if elasticities are known, they can be used to show the extent of pass-on; it overlooks the Court's major premise that the necessary elasticities are unknowable.

The essential flaw in treating a functional equivalent of a preexisting, fixed-quantity, cost-plus contract as an exception to the general no-pass-on rule is that, unlike such a contract, the functional equivalent does not "circumvent complex market interactions." 107 It is merely a shorthand way of saying that, in a particular market, those interactions combine to give an overcharge an effect similar to the effect under a literal contract. Rather than showing complete pass-on by the "easy to prove" terms of a contract, ${ }^{108}$ the proponent of the functional equivalent version of passon must prove the existence of the relevant market forces and the result of their interactions. But these forces and the effect of their combination are precisely the factors that the Supreme Court has identified as making it impossible to trace the absorption of an overcharge in the real world. ${ }^{109}$

The Illinois Brick Court concluded that "Hanover Shoe itself implicitly discouraged the creation of exceptions to its rule ... and we adhere to the narrow scope of exemption indicated by our decision there."110 Nothing in the policies that led the Court to make that statement supports a belief that the "narrow scope" is broad enough to accommodate functional equivalence. ${ }^{111}$

${ }^{10 s}$ Illinois Brick Co. v. Illinois, 431 U.S. 720, 741-42 (1977).

10. Id. at $742-43$.

103 Id. at $741-42 \& 742$ n. 25 .

${ }^{108}$ It assumes that the Supreme Court's concern is with the "speculative nature" of economic evidence, see In re Beef Indus. Antitrust Litigation, 600 F.2d 1148, 1163 n.19 (5th Cir. 1979), and that the Court has no objection to evaluating the extent of pass-on once elasticities are known, see id. at 1163 n.19, 1165-67 (semble).

107 Illinois Brick Co. v. Illinois, 431 U.S. 720, 736 (1977).

${ }^{103}$ Id. at 732 (quoting Hanover Shoe, Inc. v. United Shoe Mach. Corp., 392 U.S. 481, 494 (1968)).

109 Illinois Brick Co. v. Illinois, 431 U.S. 720, $742-45$ (1977); Hanover Shoe, Inc. v. United Shoe Mach. Corp., 392 U.S. 481, $492-93$ (1968).

110 Tllinois Brick Co. v. Illinois, 431 U.S. 720, 745 (1977).

111 A further reason for adhering to the literal terms of the exception rather than expanding it to include functional equivalence is a refinement of the incentive argument discussed earlier, see note 95 supra. Once there is a general bar against pass-on, and a narrow 


\section{Economic Theory and Functional Equivalence}

Somewhat ironically, despite the Supreme Court's distrust of economic analysis as a litigation tool, economic theory corroborates the result the Court reached in creating the preexisting, fixedquantity, cost-plus contract exception. Economic theory also shows that the true functional equivalent of such a contract has not been alleged in Beef Industry or the other cases that have considered the possibility ${ }^{112}$-nor could it be.

Incidence theory shows that the indirect purchaser will bear the entire overcharge, and the direct purchaser will not lose volume, only if demand is perfectly inelastic (Figure 1). Also, the indirect seller will bear the entire burden of an artificially low price, and the middleman will not lose volume, only if supply is perfectly inelastic. ${ }^{11}$ To justify shifting section 4 rights from the direct purchaser or middleman to the indirect purchaser or seller, the proponent of functional equivalence must demonstrate such perfect inelasticity of supply or demand.

The facts alleged in Pfizer, ${ }^{114}$ a case the Court rejected, or in Beef Industry, ${ }^{115}$ which the Court has not yet addressed, illustrate the difficulties of such a demonstration. First, elasticities are not immutable. They vary at different points along a given supply or demand curve. ${ }^{116}$ Even if we assume that, over a certain range, the need for antibiotics is so critical that purchasers will not buy less than a given quantity despite a price increase, above that range budgetary constraints will force curtailment of consumption and below it lower prices will encourage increased consumption and new purchasers (Figure 4). Similarly, even if we assume that, within a price range, cattle in a feed lot must be sold at the end of thirty days even if the price drops, below that range it is economi-

cost-plus exception to the bar, interjecting the additional complexities of functional equivalence would only increase the cost and diminish the chances of success of such litigation. The direct purchaser's incentive to sue would be reduced. Indirect purchasers would be unlikely to bring enough suits to make up the difference, however, in light of their own burden of proof problems and the need to split any recovery among the class of indirect purchasers.

112 Eastern Air Lines, Inc. v. Atlantic Richfield Co., 609 F.2d 497 (T.E.C.A. 1979) (dictum); Phillips v. Crown Petroleum Corp., 602 F.2d 616 (4th Cir. 1979) (dictum) (semble). See note 76 supra.

11s See Figure A, supra note 26.

114 West Virginia v. Chas. Pfizer \& Co., 314 F. Supp. 710 (S.D.N.Y. 1970), aff'd, 440 F.2d 1079 (2d Cir. 1971), cert. denied, 404 U.S. 871 (1974), overruled, Illinois Brick Co. v. Illinois, 431 U.S. 720, 743 n.28, 744 (1977).

${ }^{115}$ See text at note 67 supra.

116 See, e.g., P. SAMURLSON, supra note 16, at 380-87. 
cally reasonable to shoot the cattle rather than sell them, and above that range additional production is called forth (Figure 5).

FIGURE 4

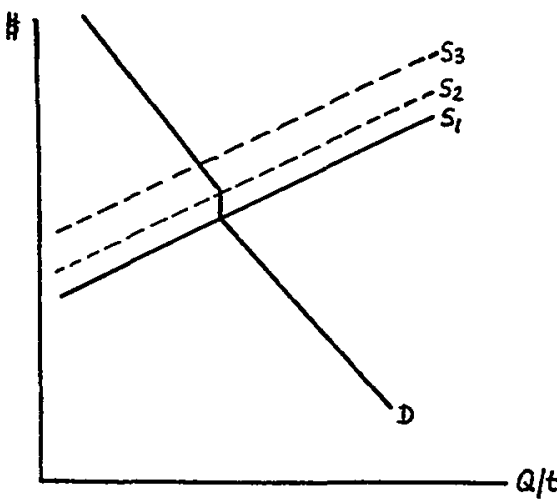

FIGURE 5

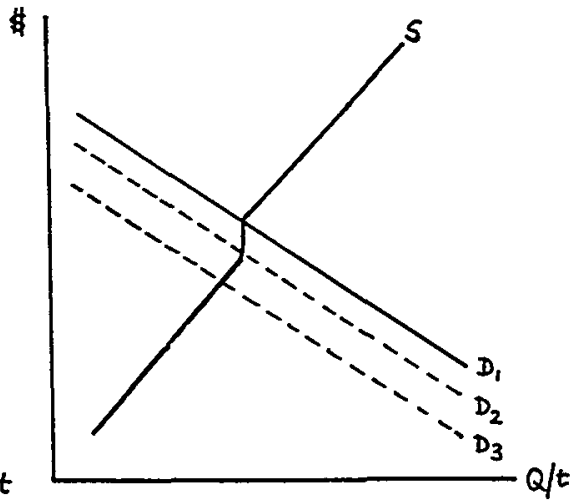

The functional equivalent argument assumes that both preand post-overcharge supply curves intersect the kinked demand curve in the region of perfect inelasticity (Figure 4), or that both pre- and post-undercharge demand curves intersect the kinked supply curve in the region of perfect inelasticity (Figure 5). This assumption requires a degree of certitude about where the kinks in the demand and supply curves occur that is impossible to attain. If the assumption is wrong, then either at the competitive level or at the level after the antitrust violation there is elasticity of demand (Figure 4) or supply (Figure 5). The result is in conflict with the Supreme Court's decisions and with incidence theory: pass-on is incomplete and apportionment is theoretically indicated (Figure 3). ${ }^{117}$ Giving the right to recover treble damages in this situation to the person who dealt directly with the antitrust violator best effectuates the compensatory and deterrent aims of private antitrust enforcement.

The more important point about elasticities is that they change over time, with demand and supply functions becoming more elastic as people adjust to changes in price. ${ }^{118}$ Consumers will substitute away from or toward a good, depending on whether its price goes up or down; suppliers will increase or decrease production in response to the same change. The consequence of this gen-

112 See also Figure C, supra note 26.

118 See, e.g., P. SAmuglson, supra note 16, at 387-88; Landes \& Posner, supra note 5, at 619-20; Schaefer, supra note 15, at 893-97. 
eral proposition is that, if the conditions for true functional equivalence existed at all in the situations supposed above, they would be evanescent. Courts would need to determine when the perfectly inelastic regions of the demand and supply curves began to exhibit elasticity. After that point, the direct purchaser or the middleman would be entitled to any recovery. The task would be at least as complex and fruitless as trying to apportion damages; the only difference would be that instead of attempting to prove exact amounts of pass-on, the proponent would be trying to establish how long demand or supply had remained perfectly inelastic. The line-drawing problems would be immense and the value of the recovery, if it were properly limited to the period of complete passon, too trivial to justify the difficulty.

The complexities of making the functional equivalent of the preexisting, cost-plus, fixed-quantity contract in fact equivalent suggest that proponents of the doctrine have something less exacting in mind. "Functional equivalence," Judge Wisdom argues, "is not lost simply because the proponent of passing-on theory cannot demonstrate that the middleman suffered no loss in volume.... The middleman's loss of volume and the indirect purchaser's absorption of the overcharge are wholly separable items of damage." 110 The court and the academic adherents of functionalism are willing to bring transactions within the cost-plus exception if there is a high degree of inelasticity, ${ }^{120}$ either of demand in the monopoly case or of supply in the monopsony situation. Both incidence theory and the Supreme Court decisions require more. Incidence theory shows that any deviation from perfect inelasticity takes the situation out of the complete pass-on illustrated by Figure 1 and

11. In re Beef Indus. Antitrust Litigation, 600 F.2d 1148, 1164 (5th Cir. 1979). Judge Wisdom also seems to approve the suggestion of some commentators that if loss of volume must ever be disproved, it is only in the defensive pass-on cases, id. at $1164 \&$ n.20. See Note, Scaling the Illinois Brick Wall, supra note 65, at 329 n.87; Note, Recovery by Indirect Purchasers, supra note 65, at 1455 n.69. The argument is that an indirect purchaser who can prove cost-plus pricing has been injured by the overcharge and should not have to carry the burden of disproving any injury to the direct purchaser, as a defendant must. But in the absence of a fixed-quantity clause, or some equivalent guarantee of perfect inelasticity of demand, incidence theory reveals that the direct purchaser will always have been injured to some extent by the overcharge. Therefore, given the Supreme Court's reasoning in Hanover Shoe and Illinois Brick, the direct purchaser must always have the exclusive right to recover in such situations. Furthermore, the partial dispensation for the indirect purchaser would create mutuality and inconsistent judgment problems of the sort discussed in Illinois Brick, 431 U.S. at 729-36.

${ }^{120}$ In re Beef Indus. Antitrust Litigation, 600 F.2d 1145, 1164 n.20, 1165-66 (5th Cir. 1979). 
into the apportionment problems illustrated by Figure 3. Moreover, in practical terms, deciding what degree of inelasticity justifies suspending the pass-on prohibition will undo whatever gains in administrability and efficient enforcement the prohibition is designed to achieve.

Judge Wisdom thought that the Supreme Court nonetheless sanctioned such a result, because even "[i]n the cost-plus contract case itself, the middleman is likely to have suffered a loss of volume and hence profits as a result of the overcharge. His higher selling price will likely have caused potential customers to forego his product."121

Judge Wisdom and the Supreme Court are using lost volume at cross-purposes. ${ }^{122}$ Economically, it is true that the overcharge itself and the resulting loss in the middleman's volume are separate kinds of damage stemming from the price-fixing. But the importance of disproving loss in volume does not come from the need to negate any damages that flow directly from that loss. Rather, loss of volume is important because only if there is no loss of volume is there perfect inelasticity of demand; only if there is perfect inelasticity of demand is there complete pass-on; and only if there is complete pass-on is there no need to apportion the damages represented by the overcharge itself and no risk of the proof problems that led the Court to prohibit the use of pass-on theory generally. ${ }^{123}$

In effect, the Supreme Court classifies each preexisting, fixedquantity, cost-plus contract as a separate market. Within that market the interactions of market forces can be traced because they cannot change. Each element of the exception is necessary to insure immutability. The contract must be created before the antitrust violation so that the parties cannot take the overcharge into account in structuring their transaction. The fixed-quantity provi-

121 Id. at 1164.

122 To be fair, it should be noted that the ambiguity arose because the Court in Hanover Shoe said that the price-fixer must show that an overcharge had no effect on the direct purchaser's actual or potential profits per unit or sales volume, in order to negate any possibility of harm to the direct purchaser. Hanover Shoe, Inc. v. United Shoe Mach. Corp., 392 U.S. 481,493 (1968). The Court seemed to be regarding volume loss as a compensable item of damage. Illinois Brick clarified that the importance of such a loss in the pass-on context is that it indicates elasticity and therefore apportionment problems. Illinois Brick Co. v. Illinois, 431 U.S. 720, 737, 741 (1977).

${ }^{123}$ This conclusion is reached by taking Illinois Brick as a clarification of Hanover Shoe; it is reinforced by incidence theory as illustrated in Figure 1, and for monopsony in Figure C, supra note 26 . See note 122 supra. 
sion insures that the amount to be bought (or sold) remains the same before and after the price-fixing - that is, that demand (or supply) remains perfectly inelastic. The price term, which is neither fixed ${ }^{124}$ nor left open, ${ }^{125}$ allows the full amount of the increase (or decrease) to be shifted onto the indirect purchaser (or indirect seller). ${ }^{126}$

The functional equivalent of a preexisting, fixed-quantity, cost-plus contract lacks one or more of these necessary elements. If it did not, it would satisfy the exception's literal terms. It therefore does not guarantee proof of complete pass-on. Instead, it reintroduces all those complexities that the Court sought to avoid and that even incidence theory can solve only in hypothetical cases.

\section{ConClusion}

In Illinois Brick and Hanover Shoe the Supreme Court was confronted with the complexities of proof associated with apportioning damages between people who deal directly with a pricefixer and people whose relationship to the price-fixer is more remote. The Court dealt with the apportionment problem by creating a general rule that recovery of damages under the Clayton Act be on an all-or-nothing basis, and that the right of recovery be given to the party who dealt directly with the price-fixer. The Court also created a narrow exception to the general rule, to cover those cases in which all harm to that party can be expeditiously and conclusively disproved. If the validity of the general rule against pass-on is taken as given, then the policies the rule is meant to serve, the cases that have explicated it, and the economic

${ }^{124}$ A fixed price makes pass-on impossible.

${ }^{125}$ An open-price term will be interpreted as calling for a "reasonable" price, arrived at in good faith, U.C.C. $\S 2-305(1)$-(2). The parties could therefore negotiate it after the pricefixing.

${ }^{128}$ There is a theoretical sense in which the cost-plus term is superfiuous. As the explanatory text preceding Figure 1 shows, see text at notes 22-29 supra, the effect of an overcharge will be to raise the supply curve by the amount of the overcharge (Figures 1-3); where demand is perfectly inelastic the full amount of the overcharge is passed on (Figure 1). There are also senses in which the cost-plus term is necessary, however. Because it permits the direct purchaser to pass on the entire overcharge and still fulfill his contract, it need not be renegotiated. If it is in fact not renegotiated, the direct purchaser is not looking toward future contracts, and it is therefore sensible to treat this particular contract as constituting a market. Furthermore, cost-plus simplifies proof. The direct purchaser who contracts on that basis makes an explicit allocation of the whole overcharge. Under a rule-ofthumb markup, by contrast, the indirect purchaser would have to furnish independent proof of the amount of the overcharge. 
theory that underlies it all call for giving the cost-plus exception a narrow construction and rejecting the functional equivalent argument. ${ }^{127}$

Joseph H. Andersen

${ }^{127}$ Denying the indirect purchaser the right to recovery does not leave it defenseless against the antitrust violator. It still can get an injunction under section 16 of the Clayton Act, 15 U.S.C. $\$ 26$ (1976), to stop illegal price fixing. See In re Beef Indus. Antitrust Litigation, 600 F.2d 1148, 1167 (5th Cir. 1979); Mid-West Paper Prods. Co. v. Continental Group, Inc., 596 F.2d 573, 589-95 (3d Cir. 1979).

For an analysis of the case law reaching the opposite conclusion, that functional equivalence is a useful doctrine, see 33 VAND. L. REv. 481 (1980). 